\title{
Pengaruh Kemampuan Manajerial Kepala Sekolah dan Penggunaan Media Pembelajaran oleh Guru terhadap Prestasi Belajar Siswa
}

\author{
Tristiniar, Edi Harapan, Destiniar \\ Universitas PGRI, Palembang, Sumatera Selatan, Indonesia \\ Corresponding author: Tristiniar (e-mail: tristiniar02@gmail.com)
}

\begin{abstract}
Abstrak: Penelitian ini bertujuan untuk menguji 1) pengaruh kemampuan manajerial kepala sekolah terhadap prestasi belajar siswa, 2) pengaruh penggunaan media pembelajaran oleh guru terhadap prestasi belajar siswa, dan 3) Pengaruh kemampuan manajerial kepala sekolah dan penggunaan media pembelajaran oleh guru terhadap prestasi belajar siswa. Penelitian ini menggunakan metode kuantitatif. Pengumpulan data dilakukan dengan angket, dan dokumentasi. Data dianalisis secara deskriptif dengan menggunakan program SPSS versi 16 for windows. Dari hasil penelitian dapat disimpulkan bahwa 1) ada pengaruh kemampuan manajerial kepala sekolah $\left(\mathrm{X}_{1}\right)$ terhadap prestasi belajar siswa (Y) di SMA se-kecamatanTanjung Raja, 2) ada pengaruh penggunaan media pembelajaran oleh guru $\left(\mathrm{X}_{2}\right)$ terhadap prestasi belajar siswa $(\mathrm{Y}) \mathrm{di}$ SMA se-kecamatan Tanjung Raja, 3) ada pengaruh yang signifikan antara kemampuan manajerial kepala sekolah $\left(\mathrm{X}_{1}\right)$, dan penggunaan media pembelajaran oleh guru $\left(\mathrm{X}_{2}\right)$ terhadap prestasi belajar siswa (Y). Implikasi dalam penelitian ini adalah: 1) kepala sekolah adalah pemimpin pendidikan dalam tingkatan satuan pendidikan yang bertanggung jawab sepenuhnya terhadap kualitas pendidikan dan juga maju mundurnya sekolah yang dipimpinnya. kepala sekolah juga merupakan seorang figur yang harus menjadi teladan bagi semua yang ada di lingkungan sekolah; 2) Penggunaan media pembelajaran oleh guru memberikan menjadikan proses belajar mengajar lebih menyenangkan, membangkitkan keinginan dan minat baru, meningkatkan motivasi dan rangsangan kegiatan belajar, bahkan berpengaruh secara psikologis kepada peserta didik.
\end{abstract}

Kata kunci: kemampuan manajerial kepala sekolah, media pembelajaran, prestasi belajar.

\section{The Effect of Principal Managerial Competencies and the Use of Learning Media by Teachers on Student Achievement}

\begin{abstract}
The objective of the study was to know, 1) the influence of the principal's managerial competencies on student achievement, 2) the influence of the use of learning media by teachers on student achievement, and 3) the influence of the principal's managerial competencies and the use of learning media by teachers on student achievement. This research used quantitative methods. Data collection used questionnaire and documentation. Data were analyzed descriptively using SPSS version 16 for windows. From the results of this study it can be concluded that 1) there was an influence of the principal's managerial competencies on student achievement, 2) there was an influence of the use of learning media by teachers on student achievement, 3) there was significant influence between principal's managerial competencies and the use
\end{abstract}


of learning media by teachers on student learning achievement. The implication of this study was: 1) headmaster as leader of the school who has responsibility for education quality and also the progress of the school he leads. He was a figure who must be a role model for everyone in the school; 2) The facilities of education must be used in the learning process to students so that the learning process is more fun, exciting, increases motivation and stimulation of learning activities, and even affects psychologically to students.

Keywords: principal managerial competencies, learning media, learning achievement.

\section{PENDAHULUAN}

Berbicara mengenai pendidikan tentunya tidak akan terlepas dari peran seorang kepala sekolah sebagai manajer yang harus mampu memanajemen seluruh kegiatan di sekolah dan juga peran guru sebagai tenaga pendidik dalam upaya mencapai tujuan pendidikan nasional yang berkualitas. Konsep pendidikan merupakan keseluruhan proses seseorang mengembangkan kemampuan, sikap, dan berbagai bentuk prilaku lain yang dapat membentuk prilaku tertentu dalam kondisi tertentu (Harapan, 2018: 323). Hal yang paling utama dalam dunia pendidikan adalah sekolah. Sekolah yang disebut juga organisasi pendidikan merupakan suatu lembaga dimana seseorang dapat belajar untuk memperoleh berbagai ilmu pengetahuan dengan memanfaatkan media pembelajaran. Setiap sekolah harus memiliki visi, misi, fungsi dan tujuan yang telah ditetapkan.

Menurut Tim Dosen Administrasi Pendidikan UPI (2009: 85), organisasi pendidikan sebagai lembaga yang bukan saja besar secara fisik, tetapi juga mengemban misi yang besar dan mulia untuk mencerdaskan kehidupan bangsa, tentu saja memerlukan manajerial yang profesional. Dengan demikian untuk mewujudkan visi, misi, fungsi dan tujuan tersebut, sekolah harus memiliki manajemen dalam mengelola organisasi yang baik, tenaga yang profesional serta sumber daya lainnya yang dapat mendukung, sehingga tujuan pendidikan dapat tercapai. Hal ini sesuai dengan tujuan pendidikan secara nasional yang tercantum dalam pasal 3 UU SISDIKNAS No. 20 Tahun 2003, yang bertujuan mengembangkan kemampuan dan membentuk watak serta peradapan bangsa yang bermartabat.

Dalam rangka mencapai tujuan tersebut, tentunya pemerintah melalui Peraturan Pemerintah nomor 19 Tahun 2005 tentang Standar Nasional Pendidikan, menetapkan delapan Standar yang harus dipenuhi dalam melaksanakan pendidikan. Salah satu standar yang dinilai langsung berkaitan dengan mutu lulusan yang di indikasikan oleh kompetensi 
lulusan adalah standar pendidik dan tenaga kependidikan. Ini berarti bahwa untuk dapat mencapai mutu lulusan yang diinginkan, mutu tenaga pendidik (guru), dan tenaga kependidikan (kepala sekolah, pengawas, laboran, pustakawan, tenaga administrasi, pesuruh) harus ditingkatkan. Sebagai sasaran pembangunan di bidang pendidikan nasional mutu pendidikan harus ditingkatkan yang merupakan bagian integral dari upaya peningkatan kualitas manusia Indonesia secara menyeluruh. Mutu pendidikan dipengaruhi oleh beberapa faktor dan salah satu diantaranya adalah manajemen.

Menurut Tim Dosen Administrasi Pendidikan UPI (2009:104), manajemen merupakan kemampuan dan keterampilan khusus yang dimiliki oleh seseorang untuk melakukan suatu kegiatan baik secara perorangan/individu ataupun bersama orang lain/berkelompok dalam usaha mencapai tujuan suatu lembaga/organisasi secara produktif, efisien dan efektif. Untuk mewujudkan pengelolaan yang baik dalam sebuah organisasi diperlukan seorang manajer yang mempunyai kemampuan profesional dibidangnya, dan itu juga berlaku di dunia pendidikan khususnya sekolah, kualitas pengelolaan sekolah akan tergantung kepada seorang kepala sekolah yang berperan sebagai manajer. Sebagai seorang manajer, kepala sekolah mempunyai tugas dan tanggung jawab yang besar dalam mengelola sekolahnya. Untuk itu seorang kepala sekolah dituntut mampu memiliki kesiapan dalam mengelola sekolah, kesiapan pimpinan yang dimaksud adalah kemampuan manajerial yang berkenaan dengan Peraturan Menteri No.13 Tahun 2007 Tentang Standar Kepala Sekolah/Madrasah.

Selain itu untuk meningkatkan mutu pendidikan dan kualitas sumber daya manusia seyogyanya seorang pemimpin harus berperan sebagai penyelaras dalam proses kerjasama antar manusia dalam organisasinya. Seorang pemimpin harus mampu memberi contoh dan mengayomi bawahannya, memotivasi, dan menggerakkan agar semua yang ada dapat dan mau bekerja secara optimal sesuai dengan uraian tugas yang telah diberikan dan melaksanakan dengan ikhlas serta penuh tanggung jawab demi tercapainya peningkatan prestasi belajar siswa. Kenyataan di lapangan kepemimpinan kepala sekolah masih menunjukan kinerjanya yang belum optimal, hal itu di indikasikan antara lain masih minimnya kepala sekolah untuk melakukan kegiatan supervisi dan tingkat kepuasan guru terhadap kepemimpinan kepala sekolah masih rendah.

Hasil wawancara dengan para wakil kepala sekolah, banyak kepala sekolah yang melaksanakan kegiatan supervisi hanya satu kali dalam setahun, yang seharusnya rutin 
setiap satu semester. Begitu pula dengan tingkat kepuasan guru terhadap kepemimpinan kepala sekolah, hanya guru-guru tertentu saja yang menjadi perhatian kepala sekolah, kepala sekolah jarang menegur guru-guru yang bolos ataupun terlambat masuk sekolah, sehingga menimbulkan kecemburuan sosial terhadap guru-guru yang rajin melaksanakan tugas mengajar, akibatnya guru-guru merasa diperlakukan tidak adil oleh kepala sekolah. Selain itu kepala sekolah juga sering terlambat untuk datang ke sekolah (hasil wawancara dengan para guru).

Kepala sekolah sebagai leader harus mampu memberikan petunjuk dan pengawasan, meningkatkan komunikasi dan mendelegasikan tugas. Kemampuan komunikasi akan tercermin dari kemampuannya untuk berkomunikasi secara lisan dengan tenaga kependidikan dan anak didik disekolah, menuangkan gagasan dalam bentuk tulisan, serta menciptakan suasana yang nyaman bagi guru dan siswa. Selain itu seorang kepala sekolah juga harus dapat melakukan hubungan interpersonal dengan bawahannya secara baik dengan gaya manajemen yang dimilikinya. Pendidikan yang baik, sebagaimana yang diharapkan oleh masyarakat modern dewasa ini yang mengharuskan adanya pendidik yang baik.

Sebagai seorang pendidik, guru dalam penyajian materi pembelajaran wajib dan harus memperhatikan aspek-aspek individual siswa sebagai subjek yang menerima materi dalam kegiatan belajar. Belajar adalah sebuah proses yang dilakukan individu untuk memperoleh kemampuan atau kompetensi yang diingikan (Pribadi, 2011: 12). Seorang guru harus mampu memilih metode dan media dalam kegiatan pembelajaran, yang sesuai dengan kondisi kemampuan siswa di dalam kelas. Berarti teknik yang dipakai harus berorientasi pada tingkat kemampuan rata-rata siswa. Pemakaian teknik yang sesuai tentu saja ada dampaknya bagi siswa, terutama bagi siswa yang tergolong kurang cepat dalam hal kemampuan memahami suatu materi, para siswa kemungkinan akan mengalami kesulitan dalam menyerap materi dari guru, atau dapat pula dikatakan siswa tersebut mengalami kesulitan sewaktu mengikuti pembelajaran. Selanjutnya yang dimaksud media pembelajaran adalah segala sesuatu yang dapat menyalurkan atau menyampaikan pesan dari suatu sumber secara terencana, sehingga terjadi lingkungan belajar yang kondusif dimana penerimanya dapat melakukan proses belajar secara efisien dan efektif (Asyhar, 2011: 8). Oleh karena proses pembelajaran merupakan proses komunikasi dan berlangsung dalam suatu sistem, maka media pembelajaran menempati posisi yang cukup 
penting sebagai salah satu komponen sistem pembelajaran, komunikasi tidak akan terjadi jika tanpa media pembelajaran dan proses pembelajaran sebagai proses komunikasi juga tidak akan berlangsung optimal.

Jenis-jenis media pembelajaran yang digunakan harus disesuaikan dengan materi pembelajaran yang disampaikan kepada siswa pada saat kegiatan pembelajaran berlangsung. Pengelompokan jenis media pembelajaran oleh Seels \& Glasgow (1990: 181-183) dalam Arsyad (2014: 35) dibagi ke dalam dua kategori, yaitu pertama pilihan media tradisional terdiri dari visual diam yang diproyeksikan, seperti: proyeksi opaque, proyeksi overhead, slides dan film strips; visual yang tak diproyeksikan, seperti: gambar, poster, foto, charts, grafik, diagram, pameran, papan info dan papan buku, dan kedua media teknologi mutakhir yang terdiri dari media berbasis telekomunikasi, seperti: telekonferen dan kuliah jarak jauh.

Selanjutnya untuk memperoleh hasil belajar yang baik maka komponen proses harus didukung oleh pemahaman guru tentang cara-cara belajar anak yang efektif (Tim Dosen Administrasi Pendidikan UPI, 2009: 122). Hasil belajar inilah yang dinamakan prestasi siswa. Prestasi Siswa termasuk ke dalam bentuk output sekolah, prestasi belajar siswa diharapkan menunjukkan pencapaian yang tinggi dalam (1) prestasi akademik, berupa nilai ulangan harian setiap kompetensi dasar, nilai dari tugas-tugas setiap kompetensi dasar, nilai ulangan umum atau pencapaian ketuntasan kompetensi, UASBN/UNBK, karya ilmiah, lomba akademik, karya-karya lain peserta didik; dan (2) prestasi non akademik seperti: olahraga, Pramuka, PMR, Paskibra, IMTAQ, kejujuran, kesopanan, kesenian, keterampilan, kejuruan, dan sebagainya. Mutu sekolah dipengaruhi oleh banyak tahapan kegiatan yang saling berhubungan (proses) seperti perencanaan, pelaksanaan, dan pengawasan.

Sebagai lembaga pendidikan sekaligus pelayanan masyarakat (public service), menurut pengamatan peneliti di SMA se-Kecamatan Tanjung Raja Kabupaten Ogan Ilir, para gurunya masih memiliki tingkat partisipasi organisasi yang kurang memadai, tingkat profesional yang perlu ditingkatkan serta tingkat kepemimpinan yang masih sangat membutuhkan pembinaan intensif. Berdasarkan wawancara yang dilakukan peneliti terhadap 15 orang guru di SMA se-Kecamatan Tanjung Raja diketahui bahwa dalam proses belajar mengajar guru kurang menunjukkan sikap profesional sebagai seorang pengajar, hal ini ditunjukkan dengan adanya guru yang saat mengajar di dalam kelas 
belum menggunakan Rencana Program Pengajaran (RPP) yang dilaksanakan (55\%) dan guru yang sudah menggunakan Rencana Program Pengajaran (RPP) sebanyak $45 \%$. Begitu juga dengan media pembelajaran yang digunakan, sekitar 35\% guru-guru masih sangat jarang menggunakan media dalam kegiatan pembelajaran. Secara organisasional pembelajaran atau kegiatan aktivitas pengajaran guru kurang maksimal dalam kesiapan mengajar, sedangkan siswa disiapkan untuk belajar sekitar $70 \%$.

Oleh karena itu, untuk meningkatkan prestasi belajar siswa dalam rangka peningkatan mutu pendidikan di SMA se-Kecamatan Tanjung Raja Kabupaten Ogan Ilir, diperlukan upaya-upaya untuk perbaikan mutu guru. Berbagai upaya tersebut misalnya banyaknya pelatihan guru, peningkatan kualitas guru melalui MGMP, pengadaan buku dan alat pelajaran, perbaikan sarana dan prasarana, peningkatan kepemimpinan dan manajerial sekolah, tetapi ironisnya fluktuasi mutu pendidikan di SMA se-Kecamatan Tanjung Raja masih kurang maksimal. Dilihat dari jumlah tenaga pengajar, di SMA seKecamatan Tanjung Raja tenaga pengajar sudah mencukupi, begitu juga dari tingkat pendidikan sudah sesuai dengan latar belakang pendidikan dan yang telah ditetapkan oleh pemerintah, namun dari nilai rata-rata hasil ujian sekolah diketahui nilai tertinggi hanya sebesar 48,18, dan nilai terendah 32,20, hal inilah membuktikan bahwa antara tingkat pendidikan yang dimiliki guru belum sebanding dengan prestasi yang diperoleh oleh peserta didiknya. Untuk itu perlu ada penelitian yang lebih mendalam berkaitan dengan kemampuan manajerial kepala sekolah dan penggunaan media pembelajaran oleh guru terhadap prestasi belajar siswa, agar dapat memberikan sumbangan bagi kemampuan manajerial kepala sekolah dan penggunaan media pembelajaran oleh guru terhadap prestasi siswa dalam proses pembelajaran di SMA se-Kecamatan Tanjung Raja, sehingga menghasilkan efektivitas yang tinggi.

\subsection{Rumusan masalah}

Adapun rumusan masalah dalam penelitian ini sebagai berikut:

1. Apakah kemampuan manajerial kepala sekolah berpengaruh terhadap prestasi belajar siswa di SMA se-Kecamatan Tanjung Raja Kabupaten Ogan Ilir?

2. Apakah penggunaan media pembelajaran oleh guru berpengaruh terhadap prestasi belajar Siswa di SMA se-Kecamatan Tanjung Raja Kabupaten Ogan Ilir? 
3. Apakah kemampuan manajerial kepala sekolah dan penggunaan media pembelajaran oleh guru berpengaruh terhadap prestasi belajar siswa di SMA seKecamatan Tanjung Raja Kabupaten Ogan Ilir?

\subsection{Kemampuan manajerial kepala sekolah}

Manajerial merupakan kata sifat yang asal katanya adalah manajemen. Manajer adalah orang yang melakukan kegiatan manajemen (Jamali, 2013: 13). Manajerial adalah orang yang bertanggung jawab atas bawahannya dan sumber daya organisasi (Handoko, 2009:35). Kemampuan manajerial kepala sekolah adalah kemampuan seorang kepala sekolah dalam mengelola sumber daya organisasi sekolah dalam rangka mencapai tujuan sekolah yang telah ditentukan (Setat, 2018: 20). Kemampuan manajerial kepala sekolah berarti kemampuan kepala sekolah dalam menggunakan input-input manajemen dengan melaksanakan fungsi-fungsi manajemen yakni perencanaan, pengorganisasian, pengkoordinasian, pengawasan dan penilaian untuk mengatur sumber daya manusia dan sumber-sumber daya lain secara efektif dan efisien dalam pencapaian tujuan sekolah yang telah ditetapkan (Fahrudin, 2015: 28).

Kemampuan manajerial ini menunjukan bahwa kepala sekolah bertindak selaku seorang manajer. Tiga hal penting yang berkaitan dengan kepala sekolah sebagai seorang manajer adalah proses, pendayagunaan seluruh sumber organisasi, dan pencapaian tujuan organisasi yang ingin dicapai. Proses adalah suatu cara yang sistematis dalam mengerjakan sesuatu. Proses yang dimaksud disini adalah pemanfaatan input-input manajemen yang harus dilaksanakan oleh kepala sekolah yang terdiri dari "tugas, rencana, program, regulasi (ketentuan-ketentuan, limitasi, prosedur kerja)". (Ditjen Dikdasmen, 2002: 21). Dengan demikian dari uraian di atas dapat disimpulkan bahwa kemampuan manajerial kepala sekolah adalah pelaksanaan kegiatan perencanaan, pengorganisasian, pengkoordinasian, pengawasan dan evaluasi sumber-sumber daya pendidikan dalam rangka mencapai tujuan sekolah yang telah ditetapkan.

\subsection{Penggunaan media pembelajaran oleh guru}

Kata media berasal dari bahasa Latin medius yang berarti 'tengah', 'perantara' atau 'pengantar'. Dalam bahasa Arab, media adalah perantara atau pengantara pesan dari pengirim kepada penerima pesan. Penggunaan media dalam kegiatan belajar mengajar 
cenderung diartikan sebagai alat-alat grafis, photografis, atau elektronis untuk menangkap, memproses, dan menyusun kembali informasi visual dan verbal (Mais, 2016: 9). Sama halnya dengan pendapat Arsyad (2014: 3), media adalah alat-alat grafis, photo grafis, elektronis untuk menangkap, memproses, dan menyusun kembali informasi visual atau verbal yang digunakan dalam kegiatan proses belajar mengajar. Sadiman, dkk (2011: 6) menjelaskan bahwa media adalah perantara atau pengantar pesan dari pengirim ke penerima pesan. Media adalah segala sesuatu yamg berfungsi untuk membawa dan menyampaikan informasi antara sumber dan penerima informasi tersebut (Yaumi, 2018:6).

Hamdani (2011: 243) mendefinisikan media adalah komponen sumber belajar atau wahana fisik yang mengandung materi instruksional di lingkungan siswa, yang dapat merangsang siswa untuk belajar. Media adalah pengantar atau perantara yang digunakan oleh komunikator untuk menyampaikan pesan kepada komunikan dalam mencapai efek tertentu (Kustiawan, 2016: 5). Sedangkan wibawanto (2017:5) berpendapat bahwa media adalah alat yang memindahkan informasi (pesan) dari sumber kepada penerima. Media merupakan perantara komunikasi untuk meminimalkan kegagalan dalam proses komunikasi (Simamora, 2009: 64), sedangkan menurut Asyhar (2011: 5) media merupakan komponen yang sangat penting dalam suatu proses komunikasi.

Kata pembelajaran merupakan terjemahan dari istilah Bahasa Inggris, yitu "Instruction", yang diartikan sebagai proses interaktif antara guru dan siswa yang berlangsung secara dinamis. Pembelajaran adalah segala sesuatu yang dapat membawa informasi dan pengetahuan dalam interaksi yang berlangsung antara pendidik dengan peserta didik (Asyhar, 2011: 7). Pembelajaran adalah upaya yang disengaja untuk mengelola kejadian atau peristiwa belajar dalam memfasilitas peserta didik sehingga memperoleh tujuan yang dipelajari (Yaumi, 2018: 6). Dapat disimpulkan bahwa media pembelajaran adalah sesuatu yang membawa pesan-pesan atau informasi pada proses belajar mengajar antara pendidik dan peserta didik baik di dalam maupun di luar kelas yang mempunyai tujuan instruksional.

Penggunaan media pembelajaran dalam proses belajar mengajar dibutuhkan para guru untuk meningkatkan motivasi dan rangsangan belajar siswa serta meningkatkan minat dan bakat siswa. Selain itu, media digital berupaya memposisikan siswa untuk membaca dan mereproduksi teks secara kritis dan mengintegrasikan pengetahuan ke 
dalam pemikiran kritis tentang konteks di mana partisipasi media terjadi (Buckingham, 2015). Secara umum, manfaat media dalam proses belajar mengajar dapat memfasilitasi interaksi antara guru dan siswa dengan menyediakan alat bantu belajar sehingga meningkatkan partisipasi siswa dan proses belajar mengajar akan lebih efektif dan efisien (Dezuanni, 2015; Patonah, dkk., 2019).

\subsection{Prestasi belajar siswa}

Kata prestasi berasal dari bahasa Belanda "Prestasic" yang berarti hasil usaha. Prestasi adalah hasil yang telah dicapai seseorang dalam melakukan suatu kegiatan (Darmadi, 2017: 295). Prestasi adalah hasil dari suatu kegiatan yang telah dikerjakan, diciptakan, baik secara individu maupun kelompok (Hamdani, 2011: 137). Sama halnya dengan pendapat Firdianti (2018: 51) bahwa prestasi adalah hasil dari suatu kegiatan yang telah dikerjakan, diciptakan, baik secara individu maupun kelompok.

Menurut Marsetyaningsih (2014: 38) dalam mencapai prestasi yang gemilang melibatkan beberapa unsur diantaranya adalah guru, siswa, fasilitas yang mendukung, serta lingkungan di mana keberhasilan tersebut dicapai. Orang yang berprestasi adalah orang yang telah meraih sesuatu dari apa yang telah dikerjakan. Prestasi yang diperoleh bermacam-macam, seperti prestasi dalam belajar, prestasi dalam olah raga, prestasi dalam bernyanyi, prestasi dalam kebersihan dan prestasi dalam bekerja (Ardiansyah, 2011: 1619). Harahap dalam Hamdani (2011:18), memberikan batasan bahwa prestasi adalah penilaian pendidikan perkembangan dan kemajuan siswa yang berkenaan dengan penguasaan bahan pelajaran yang disajikan kepada mereka serta nilai-nilai yang terdapat dalam kurikulum. Dari beberapa pengertian tersebut dapat disimpulkan bahwa prestasi adalah hasil penilaian suatu kegiatan yang berkenaan dengan penguasaan bahan pelajaran dan disajikan kepada peserta didik yang dilakukan baik secara individu maupun kelompok dalam mencapai tujuan pembelajaran.

Belajar pada hakekatnya adalah "perubahan" yang terjadi di dalam diri seseorang setelah melakukan aktivitas tertentu (Fathurrohman, 2010: 6). Marsetyaningsih (2014: 33) mendefinisikan pengertian belajar adalah suatu perubahan yang terjadi pada setiap individu, baik dari segi tingkah laku maupun kepribadiannnya. Belajar adalah suatu proses yang kompleks yang terjadi pada diri setiap orang sepanjang hidupnya (Arsyad, 2014: 1). Proses belajar terjadi karena adanya interaksi antara seseorang dengan 
lingkungannya. Maka dari itu belajar dapat terjadi kapan saja dan di mana saja. Dapat disimpulkan mengenai makna prestasi belajar adalah hasil penilaian dari suatu aktivitas pembelajaran berupa kesan-kesan yang dimiliki siswa dalam menerima, menolak dan menilai informasi-informasi yang diperoleh dan mengakibatkan perubahan dalam diri individu secara keseluruhan, baik perubahan pengetahuan, keterampilan maupun sikap.

\section{METODE PENELITIAN}

Jenis penelitian ini merupakan penelitian kuantitatif. Jenis ini dipilih dalam penelitian ini untuk menjawab pertanyaan-pertanyaan penelitian. Penelitian ini menggunakan data berupa angka dan analisis dengan statistik. Adapun desain penelitian yang digunakan dalam penelitian ini dengan menggunakan penelitian deskripsi analitik. Menurut Sugiono (2009: 29) metode ini adalah suatu metode yang berfungsi untuk mendeskripsikan atau memberi gambaran terhadap objek yang diteliti melalui data atau sample yang telah terkumpul sebagaimana adanya tanpa melakukan analisis dan membuat kesimpulan yang berlaku umum.

\subsection{Sampel penelitian}

Sampel dalam penelitian ini seperti pada tabel 1, terdiri dari 5 SMA se-Kecamatan Tanjung Raja yaitu: SMA Negeri 1 Tanjung Raja, SMA Negeri 2 Tanjung Raja, SMA Negeri 3 Tanjung Raja, SMA Muhammadyah Tanjung Raja, dan SMA YP Puncak Gemilang Tanjung Raja. Maka sampel yang peneliti ambil berjumlah 58 orang guru(responden) dengan menggunakan rumus slovin dari137 orang guru, sedangkan pengambilan sampel untuk siswa, dengan menggunakan rumus slovin diperoleh 83 orang siswa kelas XI IPA dan XI IPS (6 kelas) dari 492 orang siswa.

\subsection{Teknik pengumpulan data.}

Penelitian ini menggunakan teknik kuesioner atau angket dan dokumentasi. Angket atau kuisoner adalah teknik pengumpulan data melalui formulir yang berisi pertanyaan yang diajukan secara tertulis pada sekumpulan orang untuk mendapatkan jawaban atau tanggapan dan informasi yang diperlukan oleh peneliti. Sedangkan metode dokumentasi dimana peneliti menyelidiki benda-benda tertulis seperti buku, majalah, dokumen, 
peraturan-peraturan dan sebagainya. Adapun sampel pada penelitian berikut ini tergambar pada tabel 1 berikut:

Tabei 1. Sampel Penelitian

\begin{tabular}{|c|c|c|c|c|c|c|}
\hline \multirow[t]{2}{*}{ No } & \multirow[t]{2}{*}{ Nama Sekolah } & \multicolumn{2}{|c|}{ Jumlah Guru } & \multirow[t]{2}{*}{ Total } & \multirow{2}{*}{$\begin{array}{l}\text { Perhitungan } \\
\text { Sampel untuk } \\
\text { siswa }\end{array}$} & \multirow{2}{*}{$\begin{array}{l}\text { Jumlah } \\
\text { Siswa }\end{array}$} \\
\hline & & $\begin{array}{l}\text { Guru } \\
\text { Tetap }\end{array}$ & $\begin{array}{l}\text { Guru } \\
\text { Tidak } \\
\text { Tetap }\end{array}$ & & & \\
\hline 1. & SMA Negeri 1 Tanjung Raja & 12 & 10 & 22 & $236 / 492 \times 83$ & 40 \\
\hline 2. & SMA Negeri 2 Tanjung Raja & 11 & 3 & 14 & $86 / 492 \times 83$ & 15 \\
\hline 3. & SMA Negeri 3 Tanjung Raja & 9 & 3 & 12 & $144 / 492 \times 83$ & 24 \\
\hline 4. & SMA Muhammadyah Tanjung Raja & - & 6 & 6 & $19 / 492 \times 83$ & 3 \\
\hline 5. & SMA YPP Gemilang Tanjung Raja & - & 4 & 4 & $7 / 492 \times 83$ & 1 \\
\hline & Total & 37 & 21 & 58 & 83 & 83 \\
\hline
\end{tabular}

Sumber: Wakil Kurikulum SMA se-Kec. Tanjung Raja

\subsection{Teknik analisis data}

Uji asumsi klasik pada penelitian ini meliputi; 1) uji normalitas dilakukan untuk mengetahui apakah residual dari populasi yang digunakan terdistribusi normal atau tidak; 2) Uji homogenitas data diperlukan untuk membuktikan persamaan variasi kelompok yang membentuk sampel; 3) Multikolinearitas adalah korelasi linear yang "perfect" atau eksak di antara variabel penjelas yang dimasukkan ke dalam model, jika antara variabel independen terjadi multikolineritas, maka nilai koefisien regresi tidak dapat ditentukan hasilnya karena dari formula OLS rumus regresi diturunkan dari asumsi data tertentu.

Adapun analisis data yang digunakan meliputi analisis korelasi, analisis regresi, uji regresi parsial (uji t), dan uji regresi berganda (uji f). Analisis korelasi mencangkup analisis korelasi linier sederhana bertujuan untuk mengetahui apakah ada hubungan antara dua variabel dan juga keeratan korelasinya, dan analisis korelasi ganda merupakan angka yang menunjukkan arah dan kuatnya hubungan antara dua variabel independen secara bersama-sama atau lebih dengan satu variabel dependen.

Sedangkan analisis regresi mencangkup regresi linier sederhana dapat diartikan sebagai suatu uji yang menyangkut sebuah variable independen dan variable dependen, dan regresi linier ganda merupakan suatu alat analisis peramalan nilai pengaruh variable bebas atau lebih terhadap variable terikat untuk membuktikan ada atau tidaknya hubungan fungsi atau hubungan kausal antara dua variabel bebas atau lebih. Uji t digunakan untuk menganalisis hasil estimasi statistik nilai parameter a dan b, apakah nilai $\mathrm{a}$, dan $\mathrm{b}$ dapat dipercaya atau berpengaruh secara signifikan. Sedangkan uji $\mathrm{f}$ tujuannya 
adalah apakah variabel independen secarabersama-sama (simultan) mampu menjelaskan variabel dependen.

\section{HASIL}

\subsection{Deskripsi data variabel kemampuan manajerial kepala sekolah $\left(\mathrm{X}_{1}\right)$}

Dari hasil analisis jawaban yang diberikan kepada 58 responden (guru) yang menjadi sampel dalam penelitian ini, diperoleh total dan rerata jawaban angket variabel kemampuan manajerial kepala sekolah $\left(\mathrm{X}_{1}\right)$. Bedasarkan data dari tabel 2, dapat dikatakan bahwa kemampuan manajerial kepala sekolah dari seluruh sub indikator menunjukkan nilai rata-rata sebesar 3,96 yang berada pada kategori baik. Jadi secara keseluruhan indikator kemampuan manajerial kepala sekolah berada pada kategori baik, yaitu berada pada interval 3,40 - 4,19 (Modifikasi Sudjana, 2015: 32). Dengan demikian maka kemampuan manajerial kepala sekolah di SMA se-Kecamatan Tanjung Raja dikatakan termasuk kategori baik.

Tabel 2. Total dan Rerata Jawaban Angket Variabel Kemampuan Manajerial Kepala Sekolah ( $\left.\mathrm{X}_{1}\right)$

\begin{tabular}{|c|c|c|c|}
\hline No & Pernyataan & Total & Rerata \\
\hline 1. & $\begin{array}{l}\text { Kepala sekolah mensosialisasikan visi dan misi sekolah kepada seluruh guru } \\
\text { dan siswa }\end{array}$ & 247 & 4,26 \\
\hline 2 & $\begin{array}{l}\text { Kepala Sekolah memberikan tugas baru kepada guru diikuti dengan petunjuk } \\
\text { pelaksanaannya yang mengacu pada visi dan misi sekolah. }\end{array}$ & 245 & 4,22 \\
\hline 3 & $\begin{array}{l}\text { Kepala Sekolah memberikan petunjuk-petunjuk pelaksanaan tugas yang jelas } \\
\text { dan lengkap meliputi berbagai hal yang diperlukan. }\end{array}$ & 246 & 4,24 \\
\hline 4 & $\begin{array}{l}\text { Kepala Sekolah memberikan petunjuk-petunjuk yang bermanfaat bagi } \\
\text { kelancaran pelaksanaan tugas-tugas guru dan siswa. }\end{array}$ & 235 & 4,05 \\
\hline 5 & $\begin{array}{l}\text { Kepala Sekolah memberikan Penjelasan-penjelasan mengenai kebijakan yang } \\
\text { berlaku yang membingungkan guru dan siswa }\end{array}$ & 229 & 3,95 \\
\hline 6 & $\begin{array}{l}\text { Kepala Sekolah memberikan penjelasan penjelasan khusus kepada guru-guru } \\
\text { bila ada kebijakan-kebijakan yang baru. }\end{array}$ & 228 & 3,93 \\
\hline 7 & $\begin{array}{l}\text { Kepala Sekolah membiarkan saja, jika terjadi kelalaian guru dalam pelaksanaan } \\
\text { tugas. }\end{array}$ & 227 & 3,91 \\
\hline 8 & $\begin{array}{l}\text { Kepala Sekolah menyediakan waktu tertentu bagi guru-guru untuk bertukar } \\
\text { pikiran tentang tugas ataupun kebijakan sekolah. }\end{array}$ & 220 & 3,79 \\
\hline 9 & $\begin{array}{l}\text { Kepala sekolah kesulitan menentukan waktu untuk membantu guru dalam } \\
\text { memecahkan masalah yang dihadapi dalam bertugas, karena kesibukannya. }\end{array}$ & 223 & 3,84 \\
\hline 10 & $\begin{array}{l}\text { Kepala Sekolah memberi bimbingan yang dapat membantu guru dalam } \\
\text { memecahkan masalah yang dihadapi dalam bertugas. }\end{array}$ & 223 & 3,84 \\
\hline 11 & Kepala Sekolah memperlakukan guru-guru secara adil dan bijaksana. & 237 & 4,09 \\
\hline 12 & Kepala Sekolah memutuskan dan mengambil seluruh kebijakan sekolah. & 235 & 4,05 \\
\hline 13 & $\begin{array}{l}\text { Kepala Sekolah memberikan tanggung jawab penuh kepada guru-guru } \\
\text { mengenai tugas-tugas yang diserahkan kepadanya. }\end{array}$ & 226 & 3,90 \\
\hline 14 & $\begin{array}{l}\text { Kepala Sekolah memberikan tugas dan tanggung jawab yang sama, baik } \\
\text { kepada guru yang kreatif maupun guru yang biasa-biasa saja. }\end{array}$ & 221 & 3,81 \\
\hline 15 & $\begin{array}{l}\text { Kepala Sekolah memperlakukan sama kepada semua guru, tanpa memandang } \\
\text { tingkat kerajinan dalam bertugas. }\end{array}$ & 222 & 3,83 \\
\hline
\end{tabular}




\begin{tabular}{clcc}
\hline No & \multicolumn{1}{c}{ Pernyataan } & Total & Rerata \\
\hline 16 & $\begin{array}{l}\text { Kepala Sekolah memeriksa daftar kehadiran guru-guru sehari-hari dalam } \\
\text { tugas, secara teratur }\end{array}$ & 232 & 4,00 \\
\hline 17 & $\begin{array}{l}\text { Kepala Sekolah memperdulikan tingkat ketercapaian target kurikulum. } \\
\text { Kepala Sekolah menegur/mengingatkan guru-guru yang tidak melaksanakan } \\
\text { tugas dengan baik. }\end{array}$ & 240 & 3,79 \\
\hline 19 & $\begin{array}{l}\text { Kepala Sekolah mengemukakan berbagai kekurangan dan kelemahan guru } \\
\text { dalam melaksanakan tugas pada saat rapat dewan guru. }\end{array}$ & 217 & 3,74 \\
\hline 20 & $\begin{array}{l}\text { Kepala Sekolah atas bimbingannya, baik secara langsung maupun tidak } \\
\text { langsung membuat guru mengucapkan terima kasih. }\end{array}$ & 226 & 3,90 \\
\hline
\end{tabular}

Sumber: Data diolah oleh peneliti

Nilai Rata-rata $\quad 3,96$

\subsection{Deskripsi data variabel penggunaan media pembelajaran oleh guru $\left(\mathrm{X}_{2}\right)$}

Dari hasil analisis jawaban yang diberikan kepada 58 responden(guru) yang menjadi sampel dalam penelitian ini, diperoleh data total dan rerata jawaban angket media pembelajaran guru $\left(\mathrm{X}_{2}\right)$.

Berdasarkan data dari tabel 3, dapat dikatakan bahwa penggunaan media pembelajaran oleh guru menunjukkan nilai rata-rata sebesar 4,10 . Secara keseluruhan indikator penggunaan media pembelajaran oleh guru pada 5 SMA se-Kecamatan Tanjung Raja berada pada kategori baik, yang berada pada interval 3,40 - 4,19 (Modifikasi Sudjana, 2015: 32). Dengan demikian maka penggunaan media pembelajaran oleh guru yang digunakan oleh guru SMA se-Kecamatan Tanjung Raja saat ini sudah dikategorikan baik.

Tabel 3. Total dan Rerata Jawaban Angket Penggunaan Media Pembelajaran oleh Guru $\left(\mathrm{X}_{2}\right)$

\begin{tabular}{clcc}
\hline No & \multicolumn{1}{c}{ Pernyataan } & Total & Rerata \\
\hline 1. & $\begin{array}{l}\text { Guru memiliki pengetahuan, pemahaman dan pengertian yang cukup tentang } \\
\text { media pembelajaran. }\end{array}$ & 256 & 4,41 \\
\hline 2 & $\begin{array}{l}\text { Guru memiliki keterampilan cara menggunakan media dalam proses } \\
\text { pembelajaran di kelas. }\end{array}$ & 257 & 4,43 \\
\hline 3 & Guru mampu membuat sendiri alat-alat media pembelajaran yang dibutuhkan. & 247 & 4,26 \\
\hline 4 & $\begin{array}{l}\text { Guru mampu mengadakan penilaian terhadap media pembelajaran yang akan } \\
\text { dan telah digunakan. }\end{array}$ & 243 & 4,19 \\
\hline 5 & $\begin{array}{l}\text { Sekolah menyediakan anggaran untuk melengkapi media pembelajaran yang } \\
\text { masih dibutuhkan. }\end{array}$ & 239 & 4,12 \\
\hline 6 & $\begin{array}{l}\text { Guru menata dan menyimpan kembali media pembelajaran, setelah guru } \\
\text { menggunakan media pembelajaran tersebut. }\end{array}$ & 239 & 4,12 \\
\hline 7 & $\begin{array}{l}\text { Guru dan siswa untuk memenuhi kebutuhannya mengenai sumber buku di } \\
\text { sekolah, dapat diperoleh pada perpustakaan. }\end{array}$ & 246 & 4,24 \\
\hline 8 & $\begin{array}{l}\text { Di sekolah tersedia laboratorium komputer yang lengkap dan tersambungkan } \\
\text { dengan internet. }\end{array}$ & 235 & 4,05 \\
&
\end{tabular}




\begin{tabular}{clccc}
\hline No & \multicolumn{1}{c}{ Pernyataan } & Total & Rerata \\
\hline 9 & $\begin{array}{l}\text { Di sekolah tersedia LCD dan Laptop untuk memberikan kesadaran akan } \\
\text { pentingnya penggunaan media audio visual dalam pembelajaran. }\end{array}$ & 239 & 4,12 \\
\hline 10 & $\begin{array}{l}\text { Di sekolah tersedia sarana dan prasarana olahraga secara lengkap. } \\
11\end{array}$ & Sekolah telah mengusahakan untuk menyediakan fasilitas laboratorium IPA. & 238 & 4,09 \\
\hline 12 & Sekolah telah menyediakan laboratorium komputer. & 235 & 4,05 \\
\hline 13 & $\begin{array}{l}\text { Guru lancar dalam menggunakan media komputer sebagai media } \\
\text { pembelajaran. }\end{array}$ & 233 & 4,02 \\
\hline 14 & $\begin{array}{l}\text { Guru sudah ahli menggunakan media komputer yang tersambungkan dengan } \\
\text { internet. }\end{array}$ & 228 & 3,93 \\
\hline 15 & $\begin{array}{l}\text { Murid lancar dalam menggunakan media komputer sebagai media } \\
\text { pembelajaran. }\end{array}$ & 218 & 3,76 \\
\hline 16 & $\begin{array}{l}\text { Sekolah telah menyediakan alat peraga secara lengkap untuk proses } \\
\text { pembelajaran Bahasa Arab, IPA dan Bahasa Inggris. }\end{array}$ & 241 & 4,16 \\
\hline 17 & $\begin{array}{l}\text { Guru dan siswa dapat bertambah ilmu dan pengalamannya karena adanya } \\
\text { perpustakaan. }\end{array}$ & 237 & 4,09 \\
\hline 18 & $\begin{array}{l}\text { Guru dan siswa dapat mencari informasi secara cepat dengan adanya media } \\
\text { komputer yang tersambung dengan jaringan internet.. }\end{array}$ & 232 & 4,00 \\
\hline 19 & $\begin{array}{l}\text { Setelah sekolah menyediakan sarana dan prasarana dalam pembelajaran secara } \\
\text { lengkap, diharapkan prestasi sekolah dapat meningkat. }\end{array}$ & 229 & 3,95 \\
\hline 20 & $\begin{array}{l}\text { Guru tidak selalu menggunakan media pembelajaran dalam setiap mengajar. } \\
\text { Nilai Rata-rata }\end{array}$ & 224 & 3,86 \\
\hline Sumber: Data diolah oleh peneliti & 4,10 \\
\hline
\end{tabular}

\subsection{Deskripsi data variabel prestasi belajar siswa (Y)}

Hasil analisis rata-rata ulangan akhir semester yang diperoleh dari 58 responden yang menjadi sampel penelitian pada 5 SMA se-Kecamatan Tanjung Raja, diperoleh data statistik deskriptif mengenai prestasi belajar siswa, dengan rata-rata skor Prestasi Belajar Siswa yaitu 72,02.

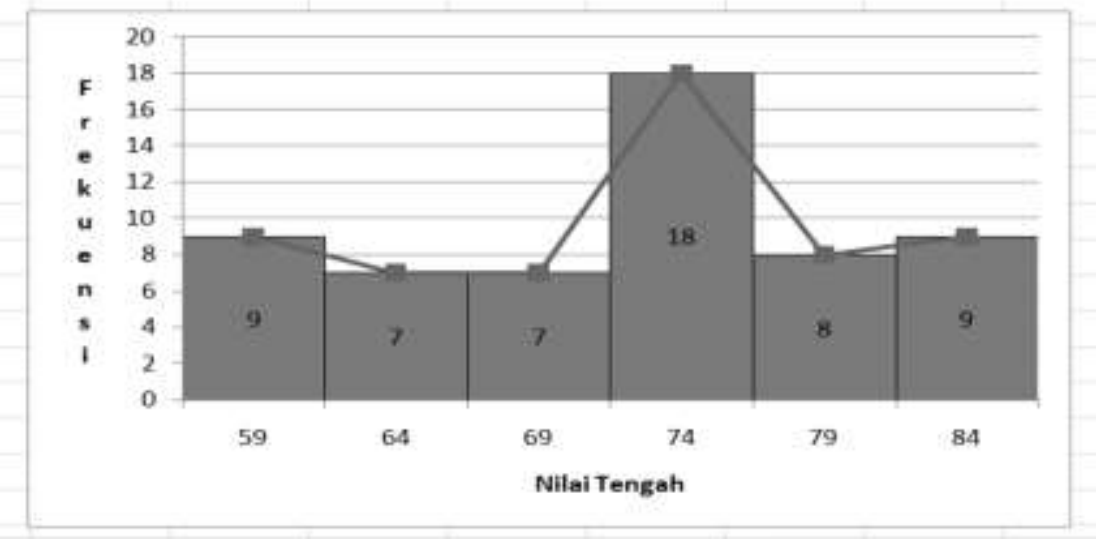

Gambar 1. Histogram Frekuensi Skor Variabel Prestasi Belajar Siswa (Y)

Dari gambar 1 mengindikasikan bahwa prestasi belajar siswa dapat dikatakan termasuk kategori baik, dimana nilai rata-rata sebesar 72,02, dengan interval nilai $71-85$ (Sudijono, 2008: 35). Dengan demikian maka prestasi belajar siswa pada 5 SMA seKecamatan Tanjung Raja Kabupaten Ogan Ilir termasuk kategori baik. 


\section{PEMBAHASAN}

\subsection{Pengaruh kemampuan manajerial kepala sekolah terhadap prestasi belajar siswa}

Kemampuan manajerial kepala sekolah yang diperoleh dari hasil penelitian berupa penyebaran angket kepada responden sebanyak 58 orang guru di SMA se-Kecamatan Tanjung Raja Kabupaten Ogan Ilir Provinsi Sumatera Selatan. Angket tersebut terdiri dari 20 item yang telah divalidasi sebelumnya.

Data yang terkumpul selanjutnya dianalisis untuk mengetahui pengaruh kemampuan manajerial kepala sekolah terhadap prestasi belajar siswa di SMA seKecamatan Tanjung Raja. Pada analisis deskriptif, skor rata-rata kemampuan manajerial kepala sekolah dari pernyataan butir item nomor satu yaitu kepala sekolah mensosialisasikan visi dan misi sekolah kepada seluruh guru dan siswa, sampai dengan pernyataan butir item nomor dua puluh yaitu kepala sekolah atas bimbingannya, baik secara langsung maupun tidak langsung membuat guru mengucapkan terimakasih, diperoleh hasil rata-rata 3,96 atau $79,20 \%$ responden yang menyatakan bahwa kemampuan manajerial kepala Sekolah SMA se-Kecamatan Tanjung Raja adalah termasuk kategori baik. Jadi secara keseluruhan indikator kemampuan manajerial kepala sekolah berada pada kategori baik, yaitu berada pada interval 3,40 - 4,19 (modifikasi Sudjana, 2015: 32).

Analisis inferensial menunjukkan hasil bahwa secara parsial variabel kemampuan manajerial kepala sekolah memlliki pengaruh yang signifikan terhadap prestasi belajar siswa, dimana dari hasil uji parsial (uji t) signifikansi t bernilai 0,004. Hal ini berarti bahwa kepala sekolah dalam melaksanakan tugas dan peranannya sudah terlaksana dengan baik atau sesuai dengan yang diharapkan. Hal ini sesuai dengan pendapat Hendarman (2015: 3), yang menjelaskan bahwa kepala sekolah sangat berperan dalam pengelolaan sekolah yang baik, yang meliputi kemampuan untuk menentukan tujuan organisasi, memotivasi prilaku pengikut untuk mencapai tujuan, dan mempengaruhi bawahan dalam memperbaiki kelompok maupun budayanya. Dengan kepemimpinan kepala sekolah yang baik tentunya dapat menciptakan kondisi-kondisi yang memungkinkan bagi lahirnya iklim kerja dan hubungan antar manusia yang harmonis dan kondusif. 
Selain itu, dengan kemampuan manajerial kepala sekolah yang baik, dapat mempermudah pencapaian mutu pendidikan di SMA se-Kecamatan Tanjung Raja dan juga merupakan kekuatan dalam rangka mempertahankan dan meningkatkan kemampuan manajerial kepala sekolah di SMA se-Kecamatan Tanjung Raja. Hal ini sejalan dengan pendapat Muhaimin (2009: 3) bahwa kepala sekolah adalah salah satu komponen pendidikan yang paling berperan dalam meningkatkan pendidikan menuju keberhasilan sekolah. Senada dengan pendapat Darmadi (2018: 3), kepala sekolah merupakan salah satu komponen pendidikan yang paling berperan dalam meningkatkan mutu pendidikan. Selain itu Mulyasa (2015: 1), menjelaskan bahwa kepala sekolah merupakan pemimpin pendidikan tingkat satuan pendidikan, yang harus bertanggung jawab terhadap maju mundurnya sekolah yang dipimpinnya.

\subsection{Pengaruh penggunaan media pembelajaran oleh guru terhadap prestasi belajar siswa}

Data penggunaan media pembelajaran oleh guru yang diperoleh dari hasil penelitian berupa penyebaran angket kepada responden sebanyak 58 orang guru di SMA seKecamatan Tanjung Raja Kabupaten Ogan Ilir Provinsi Sumatera Selatan. Angket tersebut terdiri dari 20 item yang telah divalidasi sebelumnya. Data yang terkumpul selanjutnya dianalisis untuk mengetahui pengaruh penggunaan media pembelajaran oleh guru terhadap prestasi belajar siswa di SMA se-Kecamatan Tanjung Raja. Dari hasil jawaban angket responden baik pada pernyataan item nomor satu yang menyatakan guru memiliki pengetahuan, pemahaman dan pengertian yang cukup tentang media pembelajaran, sampai pernyataan item nomor dua puluh yang menyatakan guru tidak selalu menggunakan media pembelajaran dalam setiap mengajar, diperoleh nilai rata-rata sebesar 4,10 yang berada pada kategori baik.

Secara keseluruhan indikator penggunaan media pembelajaran oleh guru berada pada kategori baik, yaitu berada pada interval 3,40 - 4,19, (modifikasi Sudjana, 2015: 32). Artinya media pembelajaran yang digunakan guru-guru SMA se-Kecamatan Tanjung Raja saat ini sudah berada pada kategori baik atau sudah tepat dan sesuai dengan tujuan serta fungsi (kegunaan) dari penggunaan media pembelajaran, yaitu sebagai pembawa informasi (pesan atau isi pelajaran) dalam kegiatan pembelajaran di dalam kelas, yang dapat membuat peserta didik lebih mudah memahami ataupun mengerti materi pelajaran 
yang disampaikan oleh pendidik (guru), Sehingga dapat mencapai keberhasilan belajar peserta didik, karena dengan penggunaan media yang tepat oleh guru akan mempengaruhi hasil belajar siswa yang bersangkutan.

Hal ini sesuai dengan pendapat Hamdani (2011: 243) yang menyatakan bahwa media pembelajaran merupakan media yang membawa pesan-pesan atau informasi yang bertujuan instruksional atau mengandung maksud-maksud pengajaran. Sama halnya dengan pendapat Mais (2016: 9), bahwa media pembelajaran yang digunakan pada proses pembelajaran sebagai penyalur pesan antara guru dan siswa agar tujuan pengajaran tercapai. Wibawanto (2017: 6), juga menjelaskan bahwa media pembelajaran merupakan media kreatif yang digunakan dalam memberikan materi pelajaran kepada anak didik sehingga proses belajar mengajar lebih efektif, efisien dan menyenangkan. Sedangkan Yaumi (2018: 6-7) menyatakan bahwa media pembelajaran adalah semua bentuk fisik yang digunakan pendidik untuk penyajian pesan dengan memfasilitas peserta didik dalam mencapai tujuan pembelajaran.

Sejalan dengan hasil penelitian yang dilakukan oleh Nurcahyo (2016), hasil penelitian menunjukkan bahwa: media pembelajaran aplikasi android memberikan pengaruh terhadap hasil belajar siswa. Selanjutnya, penelitian oleh Prasetya (2009), yang membuktikan terdapat pengaruh penggunaan media pembelajaran dengan pendekatan Chemo-Edutainment terhadap hasil belajar siswa. Kajian penelitian yang relevan menunjukkan bahwa hasil penelitian ini sejalan dan berdasarkan analisis data dapat dikatakan bahwa untuk variabel penggunaan media pembelajaran oleh guru $\left(\mathrm{X}_{2}\right)$ terdapat pengaruh terhadap prestasi belajar siswa (Y) di SMA se-Kecamatan Tanjung Raja.

\subsection{Pengaruh kemampuan manajerial kepala sekolah dan kenggunaan media pembelajaran oleh guru terhadap prestasi belajar siswa}

Kemampuan manajerial kepala sekolah dan penggunaan media pembelajaran oleh guru merupakan variabel bebas dan prestasi belajar siswa merupakan variabel terikat. Pada variabel bebas ini, dilakukan pengumpulan data dengan menggunakan angket sebanyak 20 item, sedangkan variabel terikat diperoleh dari hasil ujian akhir semester dua kelas XI, baik kelas XI IPA maupun kelas XI IPS dengan jumlah 83 orang siswa yang ditentukan berdasarkan perhitungan rumus slovin., dan berupa nilai rata-rata prestasi belajar siswa pada setiap guru mata pelajaran yang terpilih sebagai sampel yaitu 58 orang guru SMA 
se-Kecamatan Tanjung Raja. Data yang terkumpul, selanjutnya dianalisis. Pada hipotesis ketiga ini merupakan hipotesis simultan yaitu terdapat pengaruh kemampuan manajerial kepala sekolah dan penggunaan media pembelajaran oleh guru terhardap prestasi belajar siswa di SMA se-Kecamatan Tanjung Raja.

Hasil rata-rata nilai ujian akhir semester dua dari 58 responden adalah 72,07, yang berada pada kategori baik, dengan interval nilai antara 71 - 85 (Sudijono, 2009: 35). Jadi dari analisis hasil rata-rata nilai ujian akhir semester dua, nilai prestasi belajar siswa sudah menunjukkan nilai dengan kategori baik. Hal ini berarti kepala sekolah dalam pelaksanaan kemampuan manajerial kepala sekolah terhadap prestasi belajar siswa yang dilakukan oleh masing-masing kepala sekolah di SMA se-Kecamatan Tanjung Raja sudah terlaksana dengan baik, karena dengan adanya kemampuan manajerial kepala sekolah berarti kepala sekolah telah mampu dalam menggunakan input-input manajemen dengan melaksanakan fungsi-fungsi manajemen yakni perencanaan, pengorganisasian, pengkoordinasian, pengawasan dan penilaian untuk mengatur sumber daya manusia dan sumber-sumber daya lain secara efektif dan efisien dalam pencapaian tujuan sekolah yang telah ditetapkan.

Kemampuan manajerial ini menunjukkan bahwa kepala sekolah bertindak selaku seorang manajer di sekolah tersebut telah berhasil dengan kategori baik. Hal ini sejalan dengan pendapat Hendarman (2015: 3), yang menyatakan bahwa kepala sekolah sangat berperan dalam pengelolaan sekolah yang baik, yang meliputi kemampuan untuk menentukan tujuan organisasi, memotivasi prilaku pengikut untuk mencapai tujuan, dan mempengaruhi bawahan dalam memperbaiki kelompok maupun budayanya. Sedangkan menurut Cahyono (2017: 13) bahwa kepala sekolah harus memiliki jabatan yang memadukan kepemimpinan (leader), manajerial (manager) dan supervisor (supervisor).

Begitu juga dengan media pembelajaran yang digunakan oleh masing-masing guru di SMA se-Kecamatan Tanjung Raja dalam mencapai keberhasilan prestasi belajar siswa, sudah menggunakan media pembelajaran yang tepat dalam kegiatan pembelajaran di dalam kelas, karena dengan penggunaan media pembelajaran yang sesuai dengan tujuan dan fungsi/peranan dari media tersebut, maka informasi (pesan dan isi pelajaran) yang akan disampaikan kepada peserta didik akan berhasil sesuai yang diharapkan. Hal ini sesuai dengan pendapat Fathurrohman (2010: 65) yang menjelaskan bahwa media pembelajaran merupakan sesuatu yang dapat membawa informasi dan pengetahuan 
dalam interaksi yang berlangsung antara pendidik dengan peserta didik. Selanjutnya ditambahkan pula oleh Kustiawan (2016: 7) bahwa media pembelajaran merupakan bagian integral dari keseluruhan sistem dan proses pembelajan yang sangat penting dalam menentukan kegiatan pembelajaran. Sementara itu menurut Sudjana dan Rivai dalam kutipan Dewi dan Budiana (2018: 5), media pembelajaran bertujuan untuk meminimalisir penyampaian materi pembelajaran secara verbal, dengan membantu pembelajar lebih memahami secara konkret materi pembelajaran, memvariasikan strategi-strategi pembelajaran dan menciptakan pembelajaran berbasis student-centered.

\section{SIMPULAN}

Berdasarkan hasil penelitian dan analisis data yang telah dilakukan baik secara deskriptif maupun pengujian hipotesis dapat disimpulkan hal-hal sebagai berikut. Kemampuan manajerial kepala sekolah berpengaruh terhadap prestasi belajar siswa di SMA seKecamatan Tanjung Raja. Artinya, semakin maksimal manajerial yang diterapkan oleh kepala sekolah, maka prestasi belajar siswa akan semakin maksimal pula. Penggunaan media pembelajaran oleh guru berpengaruh terhadap prestasi belajar siswa di SMA seKecamatan Tanjung Raja. Artinya, semakin baik penggunaan media pembelajaran yang digunakan oleh guru di SMA se-Kecamatan Tanjung Raja, maka prestasi belajar siswa juga akan meningkat. Besarnya pengaruh penggunaan media pembelajaran oleh guru sangat ditentukan oleh peran kepala sekolah. Kemampuan manajerial kepala sekolah dan penggunaan media pembelajaran oleh guru berpengaruh secara bersama-sama terhadap prestasi belajar siswa di SMA se-Kecamatan Tanjung Raja. Berarti jika kemampuan manajerial kepala sekolah, penggunaan media pembelajaran oleh guru dan kemauan belajar siswa terus meningkat, dengan manajemen yang baik dan media pembelajaran yang sesuai dengan kemajuan zaman, maka tentu akan meningkatkan prestasi belajar yang lebih berkualitas.

\section{Acknowlegement}

Jurnal ini dibuat dari tesis Tristiniar dengan karya sendiri di bantu oleh Bapak Dr. H. Edi Harapan, M.Pd., sebagai pembimbing utama, dan Ibu Dr. Destiniar, M.Pd, sebagai pempimbing pendamping. Terima kasih atas segala bimbingan dan arahannya dalam penyempurnaan jurnal ini. 


\section{DAFTAR PUSTAKA}

Ardiansyah, B. (2011). Berprestasi tujuan hidupku. Jakarta: Bumi Aksara.

Arsyad, A. (2014). Media pembelajaran. Jakarta: PT RajaGrafindo Persada.

Asyhar, H. R. (2011). Kreatif mengembangkan media pembelajaran. Jakarta: Gaung Persada (GP) Press Jakarta.

Buckingham, D. 2015. "Do we really need media education 2.0? teaching media in the age of participatory culture". In New Media and Learning in the 21st Century, edited by T. B. Lin, V. Chen, and C. Chai, 9-21. Education Innovation Series. Singapore: Springer.

Cahyono, Y. (2017). Menapaki potensi kepemimpinan calon kepala sekolah/madrasah. Aqeela Cipta Media: Sukoharjo.

Darmadi. (2017). Pengembangan Model dan metode pembelajaran dalam dinamika belajar. Yogyakarta: CV. Budi Utama.

Darmadi. (2018). manajemen sumber daya manusia kekepalasekolahan. Yogyakarta: CV. Budi Utama.

Dezuanni, M. (2015). The building blocks of digital media literacy: socio-material participation and the production of media knowledge. Journal of Curriculum Studies, 47 (3): 416-419.

Ditjen Dikdasmen. (2002). Surat edaran direktur jenderal manajemen pendidikan dasar dan menengah.

Fahrudin, Adi Arif (2015). Tesis. pengaruh manajemen kepala sekolah dan media pembelajaran guru terhadap prestasi belajar siswa di MTs Negeri Sumberlawang Kabupaten Sragen. Institut Agama Islam Negeri Surakarta.

Fathurrohman, P. (2010). Strategi belajar mengajar. Bandung: PT. Rafika Aditama.

Firdianti, A. (2018). Implementasi manajemen berbasis sekolah dalam meningkatkan prestasi belajar siswa. Lampung: CV. Gre Publishing.

Hamdani. (2011). Strategi belajar mengajar. Bandung: CV. Putaka Setia.

Handoko, T, Hani. (2009) Manajemen personalia dan sumber daya alam. CV. Budi Utama.

Harapan, E. (2018). Pembiayaan pendidikan. Palembang: Noer Fikri Offset.

Hendarman. (2015). Revolusi kinerja. Jakarta: PT. Indeks Permata Putri Media.

Jamali, A. (2013). Pengaruh kompetensi manajerial kepala sekolah, lingkungan sekolah dan motivasi guru terhadap prestasi belajar siswa SMA Muhammadyah Kota Yogyakarta. Jurnal Akuntabilitas Manajemen Pendidikan, 1(1).

Kustiawan, U. (2016). Pengembangan media pembelajaran anak usia dini. Malang: PT.Gung Samudra.

Mais, A. (2016). Media pembelajaran anak berkebutuhan khusus. Jember Jawa Timur: CV. Pustaka Abadi.

Marsetyaningsih, H. (2014). Kegemaran membaca di perpustakaan dan prestasi belajar anak. Sukoharjo Jawa Tengah: Panembahan Senopati Garda Depan Budaya Indonesia.

Mulyasa, E. (2015). Manajemen \& kepemimpinan kepala sekolah. Jakarta: PT. Bumi Aksara.

Nurcahyo, P A. (2016). Tesis. Pengaruh penggunaan media pembelajaran terhadap hasil Belajar siswa mata pelajaran kelistrikan mesin dan konversi Energi di SMKN 2 Depok. Universitas Negeri Yogyakarta: Tidak Dipublikasikan. 
Patonah, D., Wijaya, W. M., \& Rosalin, E. (2019). Efektifitas penggunaan media gambar kartun pada pembelajaran untuk meningkatkan kemampuan berhitung peserta didik sekolah dasar. Jurnal Penelitian Pendidikan, 19(1): 37-45.

Pribadi, B. A. (2011). Model assure untuk mendesain pembelajaran sukses. Jakarta: PT. Dian Rakyat.

Sadiman, A. S., Rahardjo, R., Haryono, A., \& Rahardjito. (2011). Media pendidikan. Jakarta: Pustekkom Dibud dan PT RajaGrafindo Persada.

Setat, K. (2018). Tesis. Pengaruh kompetensi manajerial kepala sekolah, iklim sekolah dan profesionalisme guru terhadap efektivitas sekolah di SDN Kecamatan Raja Basa Bandar Lampung.

Sudijono, A. (2009). Pengantar Evaluasi Pendidikan. Jakarta: PT Taja Grafindo Persada.

Sudjana. (2015). Metode Statistika. Bandung: Tarsito.

Sugiono. (2009). Metode penelitian kuantitatif, kualitatif dan R\&D. Bandung: Alfabeta.

Tim Dosen Administrasi Pendidikan UPI. (2009). Manajemen Pendidikan. Bandung: Alfabeta.

Wibawanto, W. (2017). Desain dan pemprograman multi media pembelajaran interaktif. Jember Jawa Timur: PT. Cerdas Ulet Kreatif.

Yaumi, M. (2018). Media dan Teknologi pembelajaran. Jakarta: Prenada Media Group. 